Dept. of Biotechnology

Animal Health Research Institute, Dokki, Egypt

\title{
ELECTROPHORETIC ANALYSIS FOR PROTEIN OF SOME FOOD POISONING MICROORGANISMS ISOLATED FROM CHICKEN MEAT
}

(With 2 Tables and One Figure)

By

$$
\begin{aligned}
& \text { M.G. AGGOUR; ENSHRAH K.I. MIRA* } \\
& \text { and SOUZAN M.A. ABU-ZIED* }
\end{aligned}
$$

* Dept. of Food Hygiene, Animal Health Research Institute, Dokki, Egypt (Received at 5/2/2008)

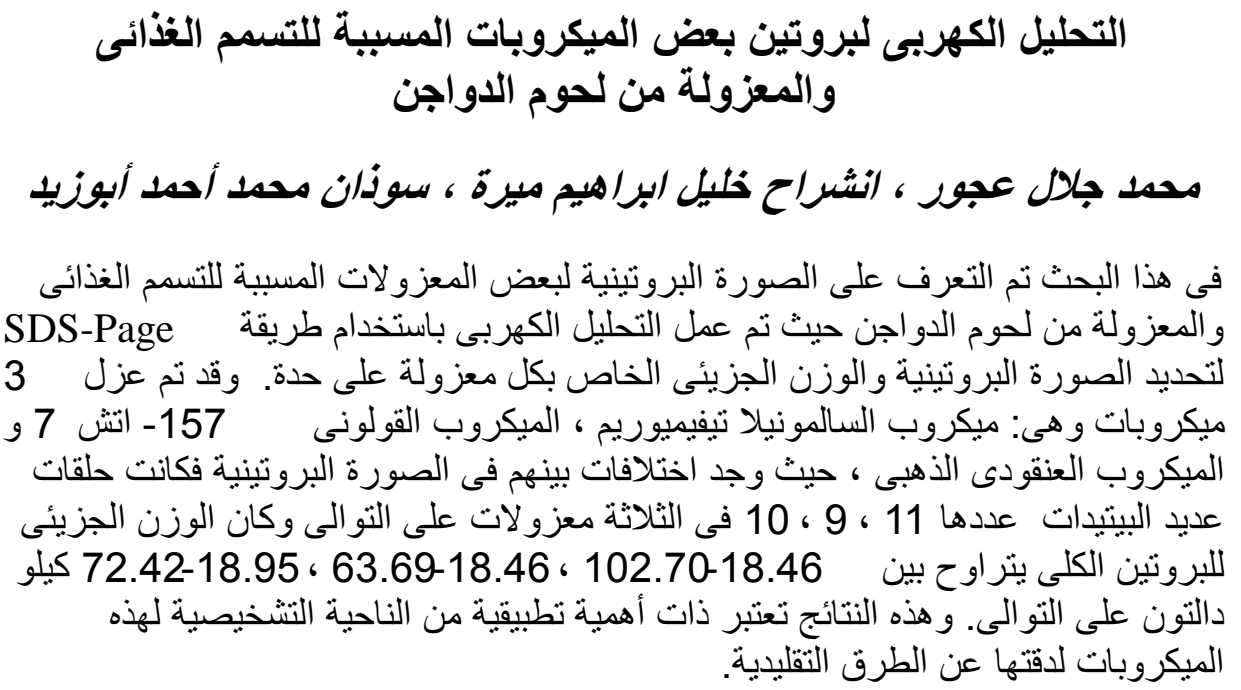

\section{SUMMARY}

In this study, SDS-PAGE analysis of major polypeptides from three strains: Salmonella typhimurium, Escherichia coli $\mathrm{O} 157 \mathrm{H} 7$ and Staphylococcus aureus isolated from chicken meat were determined. The electrophoretic profile of the three strains expressed 11, 9 and 10 proteins bands respectively. The molecular weight of the whole cell protein also showed some difference between strains which ranged from 18.48-102.70, 18.46-63.69 and 18.95-72.42 respectively. These results demonstrated that the protein profile of the three organisms isolated 
from chicken meat was characteristic for each organism which helpful in their diagnostic procedures due to its accuracy than traditional methods.

Key words: Chicken meat, electrophoresis, S. typhimurium, S. aureus, E. coli

\section{INTRODUCTION}

Bacterial pathogens found in chicken flesh can cause illness and death in humans. The most common pathogens in chicken flesh are: Salmonella, Escherichia coli and Staph organisms which are the main causes of human food poisoning. Also, chicken flesh from industrial poultry production operations has a high incidence of contamination with these pathogens.

Salmonella is among the most common causes of foodborne infections disease in the world (D' Aoust, 1989; Baird-Parker, 1990). A characteristic feature of this organism is its broad host spectrum which comprises most animal species, including mammals, birds and coldblooded animals, in addition to humans. A variety of food products, especially poultry and other types of meat products are the most important source of human infection. The risk of Salmonella infection has been heightened by the globalization of trade in food, feed and live animals and changes in production, processing and handling of food.

Poultry are a main source of Salmonella food poisoning for humans. More than 2.000 serotypes have been identified, mainly as a result of human food poisoning (Turner et al., 1998).

Salmonella (mainly S. typhimurium) are usually associated with food poisoning by virtue of their ability to colonize the alimentary tracts of livestock, particularly poultry. This results in considerable contamination of carcasses at slaughter with entry of Salmonella into human food.

Escherichia coli, O157: $\mathrm{H} 7$ has emerged as a serious, potentially life-threatening, human food-borne pathogen (Jordan et al., 1999).

Staphylococci are one of bacterial groups commonly occur on the skin of poultry during the slaughtering and processing of poultry (Pepe et al., 2006). Staphylococcus aureus is a significant cause of avian disease and may thus contaminate foods as result of processed carcases (Mead and Dodd, 1990).

Enterotoxin producing $S$. aureus is the most common cause of food-borne human illness throughout the world (Do Carmo et al., 2004 
and Le Loir et al., 2003). The foods that most frequently cause this type of poisoning are red meat and poultry and their products (Balaban and Rasooly, 2000; Genigeorgis, 1989; Kitai et al., 2005 and Wieneke et al., 1993).

Therefore the objective of this study reported here was to examine the sodium dodecyl sulphate polyacrylamide gel electrophoresis (SDS-PAGE) profile of Salmonella typhimurium: O1412 HI 1,2, Escherichia coli: O157: $H 7$ and Staphylococcus aureus isolated from examined chicken meat.

\section{MATERIALS and METHODS}

Forty eviscerated and refrigerated broiler chicken carcasses were purchased from supermarkets at Giza Governorate and brought under refrigeration to the laboratory and analyzed immediately for:

1- Isolation and identification of Salmonella according to the method approved by ISO (2002).

2- Isolation and confirmation of Staphylococcus aureus according to coagulase positive APHA (1992).

3- Isolation and identification of Escherichia coli 0157 were applied according to APHA (1992).

\section{Bacterial strains and culture conditions:-}

Salmonella typhimurium strains (Charles et al., 1994) was grown on S.S. agar plates at $37^{\circ} \mathrm{C}$ for $18-24$ hours. The colonies were incubated on tryptic Soya broth for $18-24$ hours at $37^{\circ} \mathrm{C}$. The bacteria were harvested in $10 \mathrm{~mm}$ HEPES buffer, $\mathrm{pH} 7.4$ and the suspension was centrifuged at $1.7000 \mathrm{xg}$ for 20 minutes (Barenkamp et al., 1981).

Escherichia coli, O157: H7 (Chart et al., 2000) was grown on MacConkey's bile salt neutral red lactose agar. The bacteria were cultured in nutrient broth and subculture was done on soft agar $\mathrm{pH} 7.2$ 7.4. The cells were harvested and washed twice with $0.85 \% \mathrm{Nacl}$ and suspended in $10 \mathrm{~mm}$ HEPES buffer $(\mathrm{pH} \mathrm{7.4)}$ and the suspension was centrifuged at $1.7000 \mathrm{xg}$ for 20 minutes and the supernatant were used for electrophoresis.

Staphylococcus aureus strains (Hermans et al., 2001) was grown on Columbia agar (Gibco, UK) supplemented with 5\% ovine blood, incubated overnight at $37^{\circ} \mathrm{C}$ in a $5 \% \mathrm{Co}_{2}$ enriched environment and cheeked for purity. One colony of each strain was inoculated in $5 \mathrm{ml}$ brain heart infusion (BHI) broth (Oxoid, England) and incubated for 16 hours in a $5 \% \mathrm{Co}_{2}$ enriched environment. Bacterial suspension was then 
centrifuged at $10.000 \mathrm{xg}$ for 5 minutes and the resulting supernatants were used in electrophoresis.

\section{Sodium dodecyl sulphate polyacrylamide gel electrophoresis:}

The whole cell protein extracts of S. typhimurium, E. coli O157: $H 7$ and $S$. aureus were subjected to discontinuous SDS-PAGE according to the methods of Laemmli (1970). Prior to loading onto the gel, the protein extract of bacterial isolates were heated at $100^{\circ} \mathrm{C}$ for 4 minutes in sample buffer containing 0.06 MTris, 1.2\% SDS, 5\% B-mercaptoethanol and $11.9 \%$ glycerol. The sample containing $15 \mu \mathrm{g}$ of protein in $50 \mu \mathrm{l}$ of sample buffer was loaded into each lane $(10 \mu \mathrm{l} /$ lane $)$. The protein content of each sample was determined by the modified Lowry procedure of Lowry et al., (1951) and Markwell et al., (1978). The protein was separated on SDS-polyacrylamid slab gel using Hoefer mini-gel system (SE 250, Mighty small II) with PS 500 XT power supply. The completed gel used in this study consisted of a stacking and a separating gel. The stacking gels contained final concentration of $4 \%$ acrylamide / N methylene- bisacrylamide (Sigma), 0.125 M Tris - Hcl $(\mathrm{pH}$ 6.8) and $10 \%(\mathrm{~W} / \mathrm{V})$ SDS. The separating gel contained $12 \%$ acrylamide / $\mathrm{N}$ methylene- bisacrylamide, $0.375 \mathrm{M}$ Tris $-\mathrm{Hcl}(\mathrm{pH} 8.8)$ and $10 \%(\mathrm{~W} / \mathrm{V})$ SDS. Polymerization was achieved by the addition of $0.05 \%(\mathrm{~V} / \mathrm{V}) \mathrm{N}, \mathrm{N} . \mathrm{N}^{\prime}, \mathrm{N}^{\prime}$ tetramethylene diamine (TEMED) and $0.05 \%$ (W/V) ammonium persulphate (Sigma). The electrophoresis buffer $(\mathrm{pH}$ 8.3) consisted of $0.025 \mathrm{M}$ Tris base, $0.192 \mathrm{M}$ glycine and $0.1 \%$ SDS.

Electrophoresis was performed at room temperature at a constant voltage of $100 \mathrm{~V}$ with the bromophenol blue dye reached $1 \mathrm{~cm}$ from the bottom. Gels were stained with Coomassie blue R 250. Molecular weights were estimated using Alpha Innotech, Alpha Ease FC program.

PageRuler prestained protein ladder was used as a protein marker. It is a mixture of 9 recombinant, highly purified colored proteins with the apparent molecular weights from $17 \mathrm{KDa}$ to $170 \mathrm{KDa}$.

\section{RESULTS}

Table 1: Incidence of some food poisoning micro-organisms recovered from chicken meat samples.

\begin{tabular}{|l|c|c|c|c|}
\hline \multirow{2}{*}{ Organisms } & \multirow{2}{*}{$\begin{array}{c}\text { No. of examined } \\
\text { samples }\end{array}$} & \multicolumn{2}{|c|}{ Positive samples } & \multirow{2}{*}{ Serotyping } \\
\cline { 3 - 4 } & 40 & No & $\%$ & S. typhimurium O1412 HI 1,2 \\
\hline Salmonella. & 40 & 2 & 5 & S. aureus \\
\hline S. aureus & 40 & 1 & 2.5 & O 157:H7 \\
\hline E. coli. & & & & \\
\hline
\end{tabular}


Table 2: Protein analysis of S. typhimurium, E. coli O157: $H 7$ and S. aureus.

\begin{tabular}{|c|c|c|c|c|c|c|c|c|}
\hline \multirow{2}{*}{ Band } & \multicolumn{2}{|c|}{ Marker } & \multicolumn{2}{c|}{ Lane 1 } & \multicolumn{2}{c|}{ Lane 2 } & \multicolumn{2}{c|}{ Lane 3 } \\
\cline { 2 - 9 } & Mol. Wt. & Rf & Mol. Wt. & Rf & Mol. Wt. & Rf & Mol. Wt. & Rf \\
\hline 1 & 17.00 & 0.875 & 18.46 & 0.868 & 18.46 & 0.868 & 18.95 & 0.859 \\
\hline 2 & 26.00 & 0.802 & 25.52 & 0.759 & 25.79 & 0.755 & 25.65 & 0.757 \\
\hline 3 & 34.00 & 0.688 & 28.28 & 0.724 & 27.85 & 0.729 & 28.43 & 0.722 \\
\hline 4 & 43.00 & 0.566 & 31.67 & 0.686 & 31.67 & 0.686 & 31.67 & 0.686 \\
\hline 5 & 55.00 & 0.444 & 36.01 & 0.642 & 36.01 & 0.642 & 35.82 & 0.644 \\
\hline 6 & 72.00 & 0.372 & 40.53 & 0.602 & 40.32 & 0.604 & 40.32 & 0.604 \\
\hline 7 & 95.00 & 0.299 & 46.08 & 0.559 & 45.37 & 0.564 & 45.61 & 0.562 \\
\hline 8 & 130.00 & 0.229 & 51.33 & 0.523 & 51.07 & 0.524 & 50.80 & 0.526 \\
\hline 9 & 170.00 & 0.167 & 63.04 & 0.453 & 63.69 & 0.450 & 63.04 & 0.453 \\
\hline 10 & & & 75.07 & 0.394 & & & 72.42 & 0.406 \\
\hline 11 & & & 102.70 & 0.288 & & & & \\
\hline
\end{tabular}

Lane 1: S. typhimurium

Lane 2: E. coli O157: H7

Lane 3: S. aureus

Fig. 1: Electrophoretic protein patterns of three food poisoning microorganisms isolated from chicken meat.

M: Marker contains protein of molecular weight ranged from $17 \mathrm{KDa}$ to $170 \mathrm{KDa}$.

Lane 1: Whole cell protein of $S$. typhimurium

Lane 2: Whole cell protein of E. coli O157: $H 7$

Lane 3: Whole cell protein of $S$. aureus 


\section{DISCUSSION}

Table (1) revealed the overall positive rates of $S$. typhimurium, $S$. aureus and E. coli $\mathrm{O} 157$ were 5, 22.5 and $2.5 \%$ respectively.

SDS-PAGE analysis of major polypeptides from three strains: S. typhimurium, E. coli O157: $H 7$ and S. aureus isolated from chicken meat were visualized by Coomassie staining. The protein profile of each strain was represented in Table (2) and Figure (1).

All strains have a common band with molecular weight of $36 \mathrm{KDa}$. The electrophoretic profile of whole cell protein of S. Typhimurium, E. coli O157: H7 and S. aureus expressed 11, 9 and 10 protein bands respectively. The electrophoretic protein patterns of the strains showing some degree of heterogeneity in the major band region. Similar results were obtained by Sarasombath et al., (1998); Robin and Catherine, (2000); Santos et al., (2002) and Zang et al., (2002).

In conclusion, our results demonstrated that the protein profile of the three organisms isolated from chicken meat was characteristic for each organism which is helpful in their diagnostic procedures.

\section{ACKNOWLEDGMENT}

The authors wish to thank Prof. Dr. Hosni El-Sawah and Prof. Dr. Salwa Dogheim for supplying facilitation to carry this work.

\section{REFERENCES}

A.P.H.A. (American public Health Association) (1992): Compendium of Methods for the Microbiological Examination of Foods. $2^{\text {nd }}$ Ed. American Public Health Association Washington, D.C., U.S.A.

Baird-Parker, A.C. (1990): Foodborne salmonellosis. Lancet 336, 12311235.

Balaban, N. and Rasooly, A. (2000): Staphylococcal enterotoxins. Int. J. Food Microbiol. 61: 1-10.

Barenkamp, S.J.; Munson, R.S. and Granoff, D.M. (1981): Subtyping isolates of Haemophilus influenza type b by outer membrane protein profiles. J. Infect. Dis. 143: 668-676.

Charles, S.D.; Hussien, I.; Nagraja, K.V. and Sivanandan, V. (1994): Adjuvant subunit vaccines for the control of Salmonella enteritidis infection in turkeys. Am. J. Vet. Res., 55 (5): 636642. 
Chart, H.; Smith, H.R.; La Ragione, R.M. and Woodward, M.J. (2000): An investigation into the pathogenic properties of Escherichia coli strains. J. App1. Microbiol. 89: 1048-1058.

D' Aoust, J.Y. (1989): Salmonella. In Foodborne Bacterial Pathogens. Ed. Doyle, M.P. pp. 327-445. New York, Marcel Dekker.

Do Carmo, L.S.; Cummings, C.; Linardi, V.R.; Dias, R.S.; De Suoza, J.M.; De Sena, M.J.; Dos Santos, D.A.; Shupp, J.W.; Pereira, R.K. and Jett, M. (2004): A cause of massive staphylococcal food poisoning incident. Foodborne Path. Dis. 1: 241-246.

Genigeorgis, C.A. (1989): Present state of knowledge on staphylococcal enterotoxin. Int. J. Food Microbiol. 9: 365-369.

Hermans, K.; Herdt, P.D.; Dervriese, L.A. and Haesebrouck, F. (2001): Secreted antigens as virulence- associated markers in staphylococcus aureus strains from rabbit. Vet. Microb. 81: 345-352.

ISO (2002): International Standard No. 6579: Microbiology of Food and Animal Feeding Stuffs-Horozontal method for detection of Salmonella spp.

Jordan, K.N.; Lynn, O. and Byrne, C.P. (1999): Survival of low -pH stress by Escherichia coli O 157:H7: correlation between alterations in the cell envelope and increased acid tolerance. Appl. Environ. Microbiol. 65 (7): 3048-3055.

Kitai, S.a.; Kawano, S.J.; Sato, E.; Kitagawa, K.F.; Matsumura, K.; Yasuda, R. and Inamato, T. (2005): Prevalence and characterization of Staphylococcus aureus and enterotoxigenic Staphylococcus aureus in retail raw chicken meat throughout Japan. J. Vet. Med. Sci. 67: 269-274.

Laemmli, C. (1970): Cleavage of structural proteins during the assembly of the head of bacteriophage T4. Nature, 227: 680-685.

Le Loir, Y.; Baron, F. and Gautier, M. (2003): Staphylococcus aureus and food poisoning. Genet. Mol. Res. 2: 63-76.

Lowry, O.H.; Rosebrough, N.J.; Farr, L.E. and Randall, R.J. (1951): Proteins measurement with the folin phenol reagent. J. Biol. Chemis. 193: 265-275.

Markwell, M.A.K.; Haas, S.M.; Bieder, L.L. and Tolbert, N.E. (1978): Modification of the Lowry procedure to simplify protein determination in membrane and lipoprotein sample. Anal. Biochem. 87: 206-210. 
Mead, G.C. and Dodd, C.E.R. (1990): Incidence, origin and significance of Staphylococcus aureus. J. Appl. Bacteriol. Symp. Suppl. 19: 815-915.

Pepe, O.; Blaiotta, G.; Bucci, F.; Anastasio, M.; Apon, M. and Villani, F. (2006): Staphylococcus aureus and staphylococcal enterotoxin A in breaded chicken products: Detection and behaviour during the cooking process. Appl. Environ. Microbiol. 72 (11): 7057-7062.

Robin, L.L. and Catherine, A.L. (2000): Unravelling the mysteries of virulence gene regulation in Salmonella typhimurium. Molecular Microbiol, 36: 1024-1029.

Santos, R.L.; Zhang, S.; Tsolis, R.M.; Baumler, A.J. and Adams, L.G. (2002): Morphological and molecular characterization of Salmonella typhimurium infection in neonatal calves. Vet. Path. 39 (2): 200-215.

Sarasombath, S.; Lertmemongkolechai, G. and Banchium, N. (1998): Characterization of monoclonal antibodies to protein antigen of Salmonella typhimurium. J. Clin. Microbiol. 26 (3): 508-512.

Turner, A.K.; Lovell, M.A.; Hulme, S.D.; Barber, L.Z. and Barrow, P.A. (1998): Identification of Salmonella typhimurium genes required for colonization of the chicken alimentary tract and for the virulence in newly hatched chicks. Infect. Immun. 66 (1): 2099-2106.

Wieneke, A.A.; Roberts, D. and Gilbert, R.J. (1993): Staphylococcal food poisoning in the United Kingdom, 1969-1990. Epidemiol. Infect. 110: 519-531.

Zang, S.; Santo, R.L.; Tsolis, R.M.; stender, S.; Hardt, W.D.; Baumler, A.J. and Adams, L.G. (2002): The Salmonella enterica serotype typhimurium effector proteins Sip A, Sop B, Sop D and Sop E2 act in concert to induce diarrhea in calves. Infect. Immun. 70 (7): 3843-3855. 